\title{
CHANGES IN ACCESSIBILITY OF EDUCATIONAL INFRASTRUCTURE IN RURAL AREAS - EVIDENCE FROM POLAND
}

\begin{abstract}
Agnieszka WOJEWÓDZKA-WIEWIÓRSKA, Department of Development Policy and Marketing, Institute of Economics and Finance, Warsaw University of Life Sciences, Nowoursynowska str. 166, Warsaw, Poland, agnieszka_wojewodzka@sggw.edu.pl (corresponding author)

Maciej STAWICKI, Department of Development Policy and Marketing, Institute of Economics and Finance, Warsaw University of Life Sciences, Nowoursynowska str. 166, Warsaw, Poland, maciej_stawicki@sggw.edu.pl

Social infrastructure is an important element determining local socio-economic development. The paper deals with the problem of residents' access to basic educational infrastructure. The aim of the study was to determine the accessibility to educational infrastructure in rural areas in Poland. Social and spatial accessibility to primary schools and kindergartens in rural areas was specified. Research used data provided by Statistics Poland for period 2000-2019. The article reveals that the spatial availability of educational infrastructure in rural areas has changed over time; compared to urban areas it is worse for kindergartens and better for primary schools. Social accessibility to rural kindergartens has increased significantly. Private sector and non-governmental organizations play an increasingly important role in ensuring access to educational infrastructure in rural areas in Poland. Providing access to rural education is a very important task for local authorities in Poland. Educational facilities, i.e. schools, fulfilling many non-educational functions, determine the vitality and development of local communities.
\end{abstract}

Keywords: social infrastructure, social infrastructure services, rural development, schools, kindergartens.

\section{INTRODUCTION}

Issues of underdevelopment of infrastructure and consequently problems in access to services by rural inhabitants are indicated as one of the problems that concern the development of rural areas in Poland (Kondratowicz-Pozorska, 2008; Kołodziejczyk, 2014; Klodzinski, 2015; Heffner, Klemens, 2016). The low level of equipment of rural areas with technical and social infrastructure can significantly limit socio-economic development (Bryden, 2011) and affect the satisfaction of the individual's own needs as well as the community of residents (Straka, Tuzova, 2016; Manggat et al., 2018). It is indicated that the social infrastructure is an important element of the socio-economic system at the local level (Frolova et al., 2016). Among the many functions it performs in the everyday life of rural residents, it is noted that the social infrastructure ensures the development of a territorial unit (Flora, Flora, 1993), allows to satisfy the basic needs and interests of the community (Stawicki, Vaznoniene, 2019), and determines the living conditions of the population (Wojewódzka-Wiewiórska, Atkociuniene, 2019). The development of services provided as part of the social infrastructure determines social progress. Objects of rural social infrastructure create conditions for the community to meet, communicate, maintain social bonds and contribute to maintaining the vitality of the community and its development (Atkociuniene et al., 2019). Rural social infrastructre covers various sectors and services (Swanson, 1992; Kossymbayeva, et al., 2019) provided by various social infrastructure facilities, including i.e. school, healthcare, social welfare, public passenger transport.

Particularly important for the inhabitants is the issue of development and accessibility of educational infrastructure, which can be regarded as basic and which is the responsibility of local governments in Poland. The dynamic demographic changes that have taken place in rural areas in recent years and the associated population change (large population losses, large population increases) significantly determine the demand for educational infrastructure (Wojewódzka-Wiewiórska, Stawicki, 2020). They also condition the ability of local authorities to provide access to educational services (Sigsworth, Solstad 2005; Kučerová, Kučera, 2012). On the other hand, a very important element determining the availability of educational infrastructure is the issue of implementing and financing educational investments at the local level, which is a very complex process (Napierała, Lawin, 2015). Due to the high costs of such investments, undertaking investments in educational infrastructure and the necessity to incur expenses in this area constitute a serious challenge for local authorities and the finances of territorial units, especially in rural areas. It should be noted that in rural areas, a lot of attention is given to the school not only from the point of view of providing educational services, but as an important place/centre of socio-economic life. The importance of the school for the inhabitants becomes apparent especially when the local

Copyright () 2021 The Authors. Published by Vytautas Magnus University. This is an open-access article distributed under the terms of the Creative Commons Attribution License (CC BY 4.0), which permits unrestricted use, distribution, and reproduction in any medium, provided the original author and source are credited. 
authorities want to close the village school (Kalaoja, Pietarinen, 2009; Slee, Miller, 2015; Wojewódzka-Wiewiórska, Stawicki, 2021).

Studies of spatial accessibility of public services - including education are commonly used, among others, in determining the degree to which the social needs of the inhabitants of a given area are met. According to Taylor (1999) after Walaszek, 2018, accessibility is an opportunity or possibility allowing a person living permanently in a certain area to benefit from various activities. Social and spatial accessibility of infrastructure is distinguished (Dominiak, 2012), which can be described, among others, by the following indicators: number of infrastructure facilities (e.g. primary schools) per 10 thousand inhabitants aged 7-12 (social accessibility) or per $1 \mathrm{~km}^{2}$ (spatial accessibility).

In rural areas in Poland there have been great changes in development in recent years, also due to access to EU funds, which may be used for the development of social infrastructure, which is highly capital intensive and for years underfinanced. Therefore, it is important to show how the educational infrastructure in rural areas is developing in the context of its accessibility for inhabitants. The aim of the study was to determine the accessibility to educational infrastructure in rural areas in Poland. The following research tasks were formulated: (1) to determine social accessibility to kindergartens and primary schools in rural areas and changes over time, (2) to determine spatial accessibility to educational infrastructure in rural areas, (3) to determine social and spatial accessibility to kindergartens and primary schools in rural areas in relation to urban areas.

\section{RESEARCH METHODS}

The basic educational infrastructure, i.e. kindergartens and primary schools, access to which is to be provided by local authorities as part of their own tasks, was selected for analysis. The data of the Statistics Poland were used. The time scope of the study covers the years 2000-2019. Rural areas were considered rural gminas (municipalities), which results from the availability and aggregation of data used in public statistics. In the study, accessibility to education is understood as both spatial accessibility - in relation to the area of territorial units, and social accessibility - in relation to the number of inhabitants (in this case children in school or preschool age). The following indicators were calculated: number of children aged 7-14 per 1 primary school, number of children aged 3-6 per 1 kindergarten, number of primary schools and kindergartens per 1 $\mathrm{km}^{2}$ of built-up and urbanised area. The method used was literature analysis, comparative analysis. Charts and cartograms were used for data presentation, with the use of MS Excel and QGIS software.

\section{RESEARCH RESULTS}

Currently, Poland has a model of primary education organisation introduced in $2017^{1}$. The first level for children aged 3-6 years includes kindergartens, which are not obligatory (Fig. 1). The next level of education are primary schools, where education lasts 8 years. The gmina's own tasks include establishing and running public kindergartens and primary schools (Act..., 2021). The implementation of these tasks is supported by subsidies from the state budget. Expenditures on financing educational tasks in gminas constitute a very important element of the gmina budget, on average, in rural gminas their share in total expenditure is about 40\% (Maj-Waśniowska, 2018) (in some gminas expenditure on education accounts for $60 \%$ of total budget expenditure). Gminas where the population is shrinking are in a particularly difficult situation, as a decrease in the number of children further entails changes in the system of organisation of primary education (Wojewódzka-Wiewiórska, Stawicki, 2020).

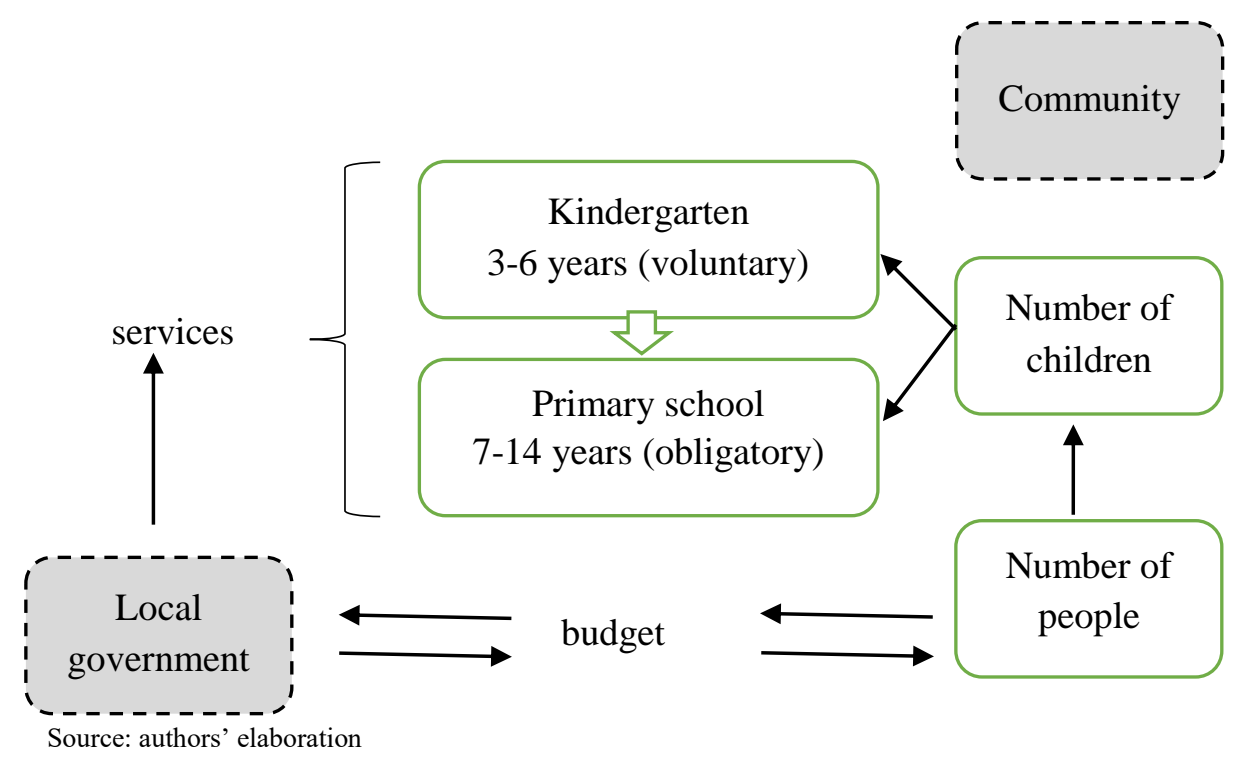

Figure 1. Organisation of education at local level in Poland

\footnotetext{
${ }^{1}$ In the analyzed period, i.e. before 2017, there was another model of education in Poland, where the primary school covered 6 years, after which the pupils learned in a 3-year middle school. The maintenance of both the primary school and the gymnasium was the gminas' responsibility.
} 


\section{Trends in social accessibility to education}

Social accessibility to kindergartens in the rural areas in Poland was during the whole period not much lower than in cities. It improved significantly over the years in all types of analysed gminas, as in 2019 there were almost 2 times fewer children per one kindergarten than in the year 2000 (Fig. 2).

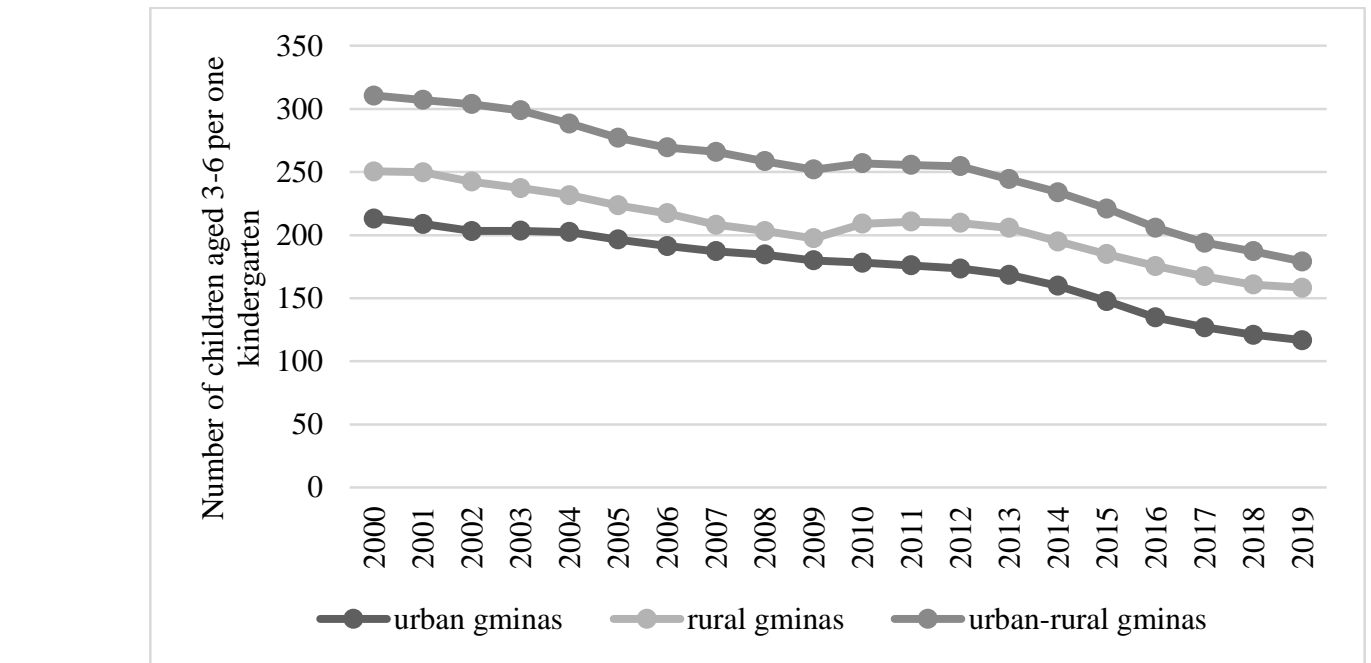

Source: authors' elaboration based on data by Statistics Poland (2021)

Figure 2. Social accessibility to kindergartens in Polish local administrative units

Social accessibility to primary schools, on the contrary, was in the rural areas almost unchanged during the analysed 20 years (Fig. 3). This was because in many, especially rural municipalities schools were being closed down as the number of children decreased due to demographic changes and declining pupils numbers.

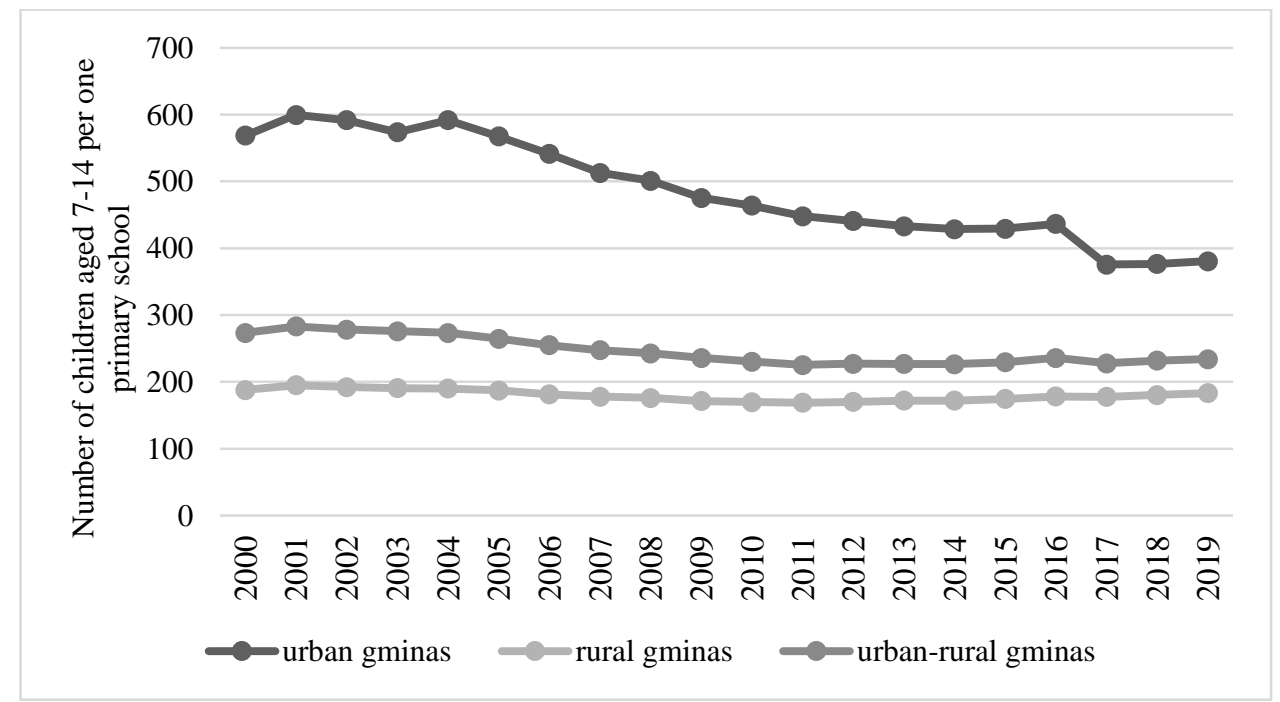

Source: authors' elaboration based on data by Statistics Poland (2021)

Figure 3. Social accessibility to primary schools in Polish local administrative units

\section{Trends in spatial accessibility to education}

The number of kindergartens per unit of built-up area was two times higher in the urban gminas than in rural and urban-rural gminas (Fig. 4). On the other hand, the accessibility has improved over the analysed period, especially in 2008-2019, which was related to the development of the pre-school network of thanks to EU funding and the increase in the number of private kindergartens (Czapiewski, Janc, 2012).

Despite general progress in the rural areas, important differences between the regions are noticeable (Fig. 5). In 3 regions which were facing depopulation and ageing (opolskie, świętokrzyskie, podlaskie) the number of kindergartens in relation to the area decreased. In southern Poland (małopolskie and podkarpackie regions) many new pre-schools were opened which increased the spatial accessibility by $61-87 \%$. 

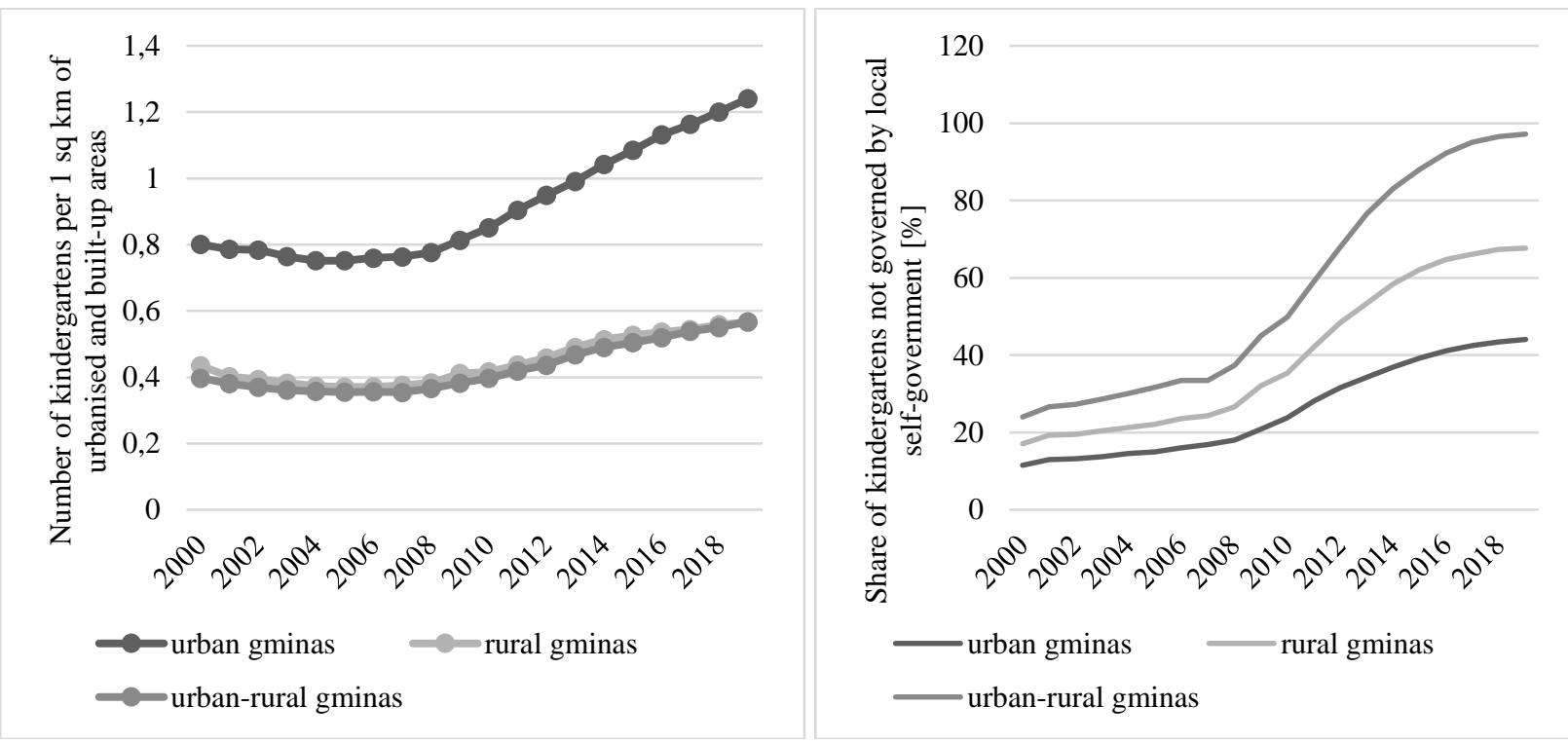

Source: authors' elaboration based on data by Statistics Poland (2021)

Figure 4. Spatial accessibility to kindergartens in Polish local administrative units and the share of private entities

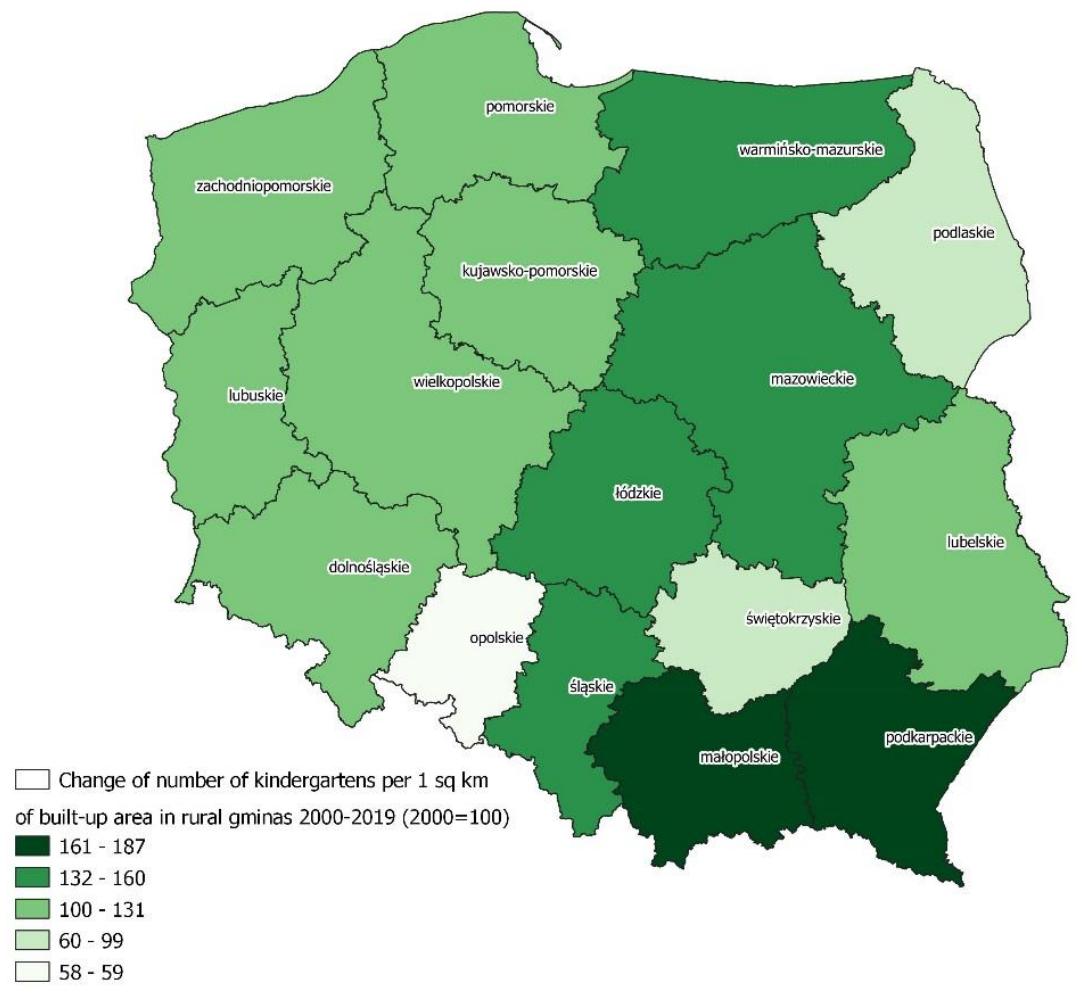

Source: authors' elaboration based on data by Statistics Poland (2021)

Figure 5. Changes of spatial accessibility to kindergartens in Polish rural local administrative units (2000-2019)

Spatial accessibility to primary schools in Polish rural areas was better than in other types of units but along with the ongoing process of school closure it was decreasing over time (Fig. 6). Unlike in the case of kindergartens, the development of non-public schools after 2010 was very strong in rural areas, which involved NGOs taking over village schools that were being closed down by the municipalities, but this did not translate into an increase in their number.

The changes of spatial accessibility were diversified spatially, as the highest decrease was observed in Eastern Poland (podlaskie, lubelskie, świętokrzyskie), where almost 35-45\% of rural schools were closed down along with demographic changes. In the southern regions the number of schools per 1 square $\mathrm{km}$ of built-up area also decreased but only by $10-20 \%$ in śląskie and małopolskie voivodships (Fig. 7). 

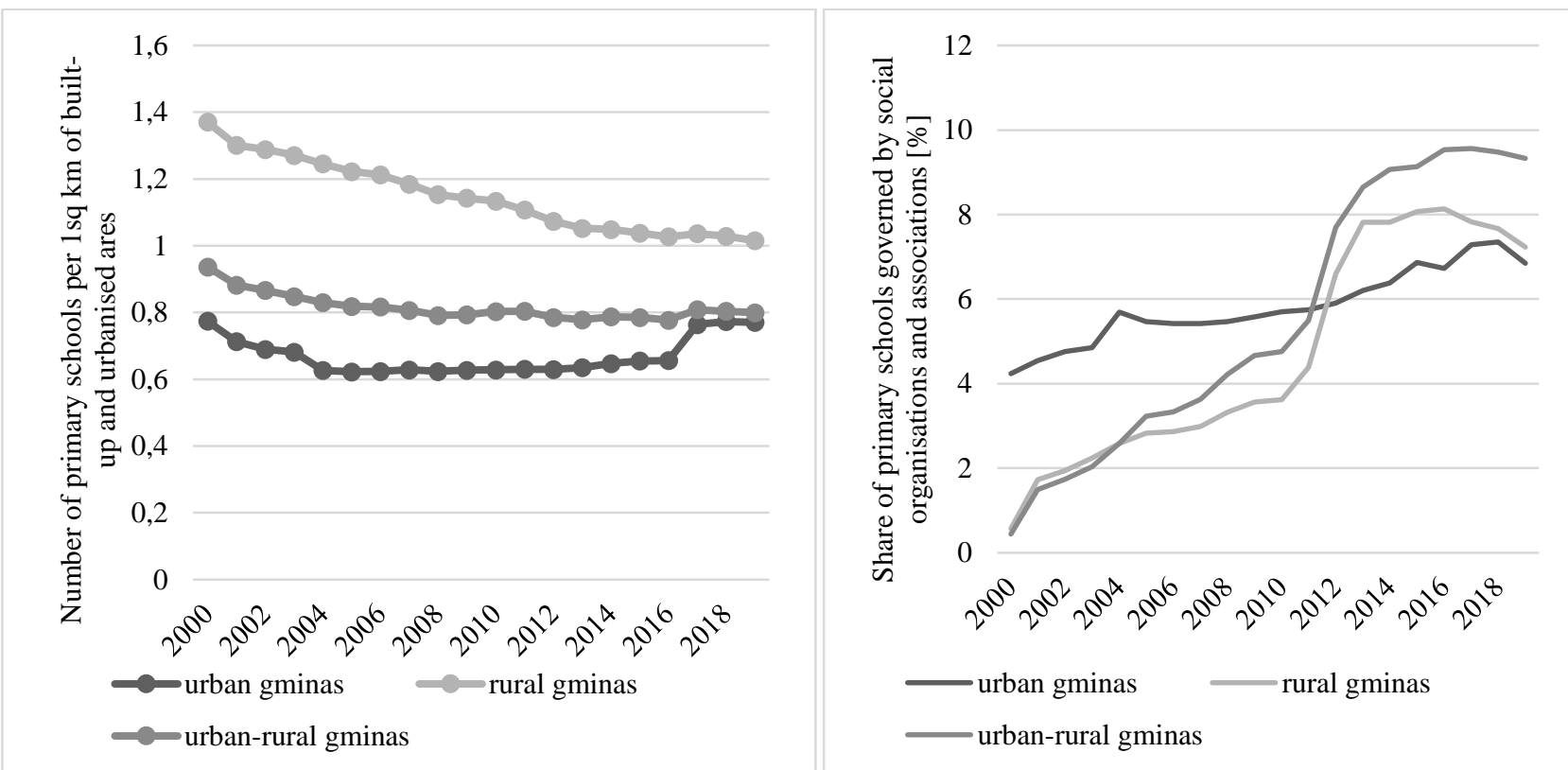

Source: authors' elaboration based on data by Statistics Poland (2021)

Figure 6. Spatial accessibility to primary schools in Polish local administrative units vs non-public schools

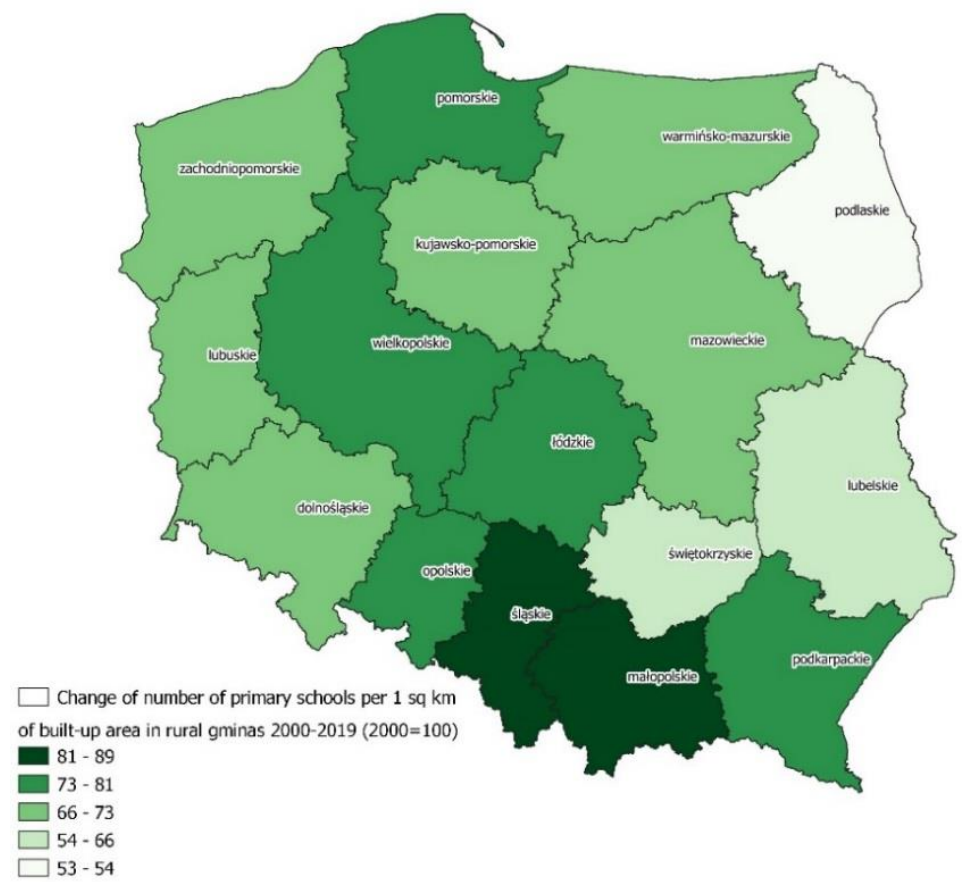

Source: authors' elaboration based on data by Statistics Poland (2021)

Figure 7. Changes of spatial accessibility to primary schools in Polish rural local administrative units (2000-2019)

\section{CONCLUSIONS AND DISCUSSION}

1. In the analysed period it was found that spatial accessibility to educational infrastructure in rural areas has changed over time and is regionally differentiated. Compared to urban areas, spatial accessibility to kindergartens in rural areas is worse, while accessibility to primary schools is better. Social accessibility to kindergartens has increased significantly in rural areas, while accessibility to schools has hardly changed, which is due to the closure of many rural schools due to the occurrence of unfavourable demographic changes.

2. Ensuring access to education is a very important task for local authorities in Poland. Expenditure on educational infrastructure is a very important item in the budgets of rural gminas, sometimes significantly burdening them. At the same time, rural local communities expect from local authorities access to high quality educational infrastructure, whose facilities (e.g. schools) perform many non-educational functions, which determine the vitality and development of local communities.

3. Local socio-economic conditions are causing changes in the organisation of education at the local level, which may translate into greater accessibility. In some rural gminas, the growing role of the private sector in providing 
places in kindergartens and the increasing importance of non-governmental organisations as an entity shaping accessibility to primary schools have been identified, which may be a rationale for undertaking detailed research in this respect.

\section{REFERENCES}

1. Act of 8 March 1990 on municipal self-government, Journal of Laws from 2021, item 1372.

2. Atkociuniene, V., Vaznoniene, G., Pakeltiene, R. 2015. Aim of the Development of Rural Social Infrastructure: a Sustainable Community. Transformations in Business \& Economics, Vol. 14, No 2A(35A), pp. 42-59.

3. Bryden, J. 2011. Rural Development Indicators and Diversity in the European Union. Available at http://citeseerx.ist.psu.edu (accessed on 05/09/2021), p. 11.

4. Czapiewski, K., Janc, K. 2012. Dostępność do edukacji, jakość kształcenia i poziom wykształcenia mieszkańców a struktura funkcjonalna gmin województwa mazowieckiego. MAZOWSZE Studia Regionalne, No 10/2012, pp. 33-51.

5. Dominiak, J. 2012. Dostępność usług publicznych na terenie województwa wielkopolskiego (Availability of Public Services in the Wielkopolskie Voivodeship). Available at http://www.umww.pl/artykuly/55886/pliki/1.dostepnoscuslugpublicznych natereniewojewodztwawielkopolskiego.pdf (accessed on 11/09/2021)

6. Flora, C. B., Flora, J. L. 1993. Entrepreneurial Social Infrastructure: a Necessary Ingredient. Annals of the American Academy of Political and Social Science, Vol. 529, No. 1, pp. 48-58. https://doi.org/10.1177/0002716293529001005

7. Frolova, E. V., Vinichenko, M. V., Kirillov, A. V., Rogach, O. V., Kabanova, E. E. 2016. Development of Social Infrastructure in the Management Practices of Local Authorities: Trends and Factors. International Journal of Environmental \& Science Education, Vol. 11, No. 15, pp. 7421-7430.

8. Heffner, K., Klemens, B. 2016. Potencjaly i strefy problemowe w zakresie świadczenia uslug publicznych na obszarach wiejskich w skali regionalnej. (Potentials and Problem Areas in the Provision of Public Services in Rural Areas at Regional Scale). Studia Obszarow Wiejskich, Vol. 42, pp. 26-28. https://doi.org/10.7163/SOW.42.2

9. Kalaoja, E., Pietarinen, J. 2009. Small Rural Primary Schools in Finland: A pedagogically Valuable Part of the School Network. International Journal of Educational Research, Vol. 48, pp. 109-116. https://doi.org/10.1016/j.ijer.2009.02.003

10. Klodzinski, M. 2015. Zagrozenia i szanse stojace przed rozwojem sektora przedsiebiorczosci wiejskiej (Threats and Opportunities Facing the Developmental sector of Rural Entrepreneurship). Wies i Rolnictwo, No. 2(167), pp. 125-138.

11. Kołodziejczyk, D. 2014. Infrastruktura w Rozwoju Społeczno-Gospodarczym Gmin w Polsce (Infrastructure in Social-Economic Development of Gminas in Poland). Research Papers of Wroctaw University of Economics, No. 360, pp. $198-207$. https://doi.org/10.15611/pn.2014.360.21

12. Kondratowicz-Pozorska, J. 2008. Analiza kierunkow rozwoju usług na terenach wiejskich wojewodztwa zachodniopomorskiego w latach 2000-2006 (Analysis of Directions of Services Development in Rural Areas of West Pomeranian Region in Years 20002006). Zeszyty Naukowe SGGW - Ekonomika i Organizacja Gospodarki Zywnosciowej, No. 68, pp. 117-126.

13. Kossymbayeva, S., Atkociuniene, V., Nukesheva, A., Balkibayeva, A. 2019. Peculiarities of Rural Social Infrastructure Management. Research for Rural Development 2019, Vol. 2, pp. 139-145. https://doi.org/10.22616/rrd.25.2019.061

14. Kučerová, S., Kučera, Z. 2012. Changes in the Spatial Distribution of Elementary Schools and their Impact on Rural Communities in Czechia in the Second Half of the 20th century. Journal of Research in Rural Education, Vol. 27(11), pp. 1-17. Available at http://jrre.psu.edu/articles/27-11.pdf

15. Maj-Waśniowska, K. 2018. Analiza znaczenia wydatków oświatowych w zależności od kategorii jednostki samorządu terytorialnego (An Analysis of the Significance of Educational Expenditures by Type of Local Government Unit). Zesz. Nauk. UEK, Vol. 1(973), pp. 129-156. https://doi.org/10.15678/ZNUEK.2018.0973.0108

16. Manggat, I., Zain, R., Jamaluddin, Z. 2018. The Impact of Infrastructure Development on Rural Communities: A Literature Review. International Journal of Academic Research in Business and Social Sciences, Vol. 8(1), pp. 650-651. https://doi.org/10.6007/IJARBSS/v8-i1/3837

17. Napierała, T., Lawin, M. 2015. Gminne inwestycje w infrastrukturę edukacyjną w łódzkim obszarze metropolitalnym w latach 2007-2013 (Municipal Investments for Educational Infrastructure in Lodz Metropolitan Area in the years 2007-2013). Acta Universitatis Lodziensis Folia Geographica Socio-Oeconomica, Vol. 20, pp. 119-138. https://doi.org/10.18778/1508-1117.20.08

18. Sigsworth, A., Solstad, K. 2005. Small Rural Schools: a Small Inquiry, Nesna University College, Interskola, Cornwall, England.

19. Slee, B., Miller, D. 2015. School Closures as a Driver of Rural Decline in Scotland: A Problem in Pursuit of Some Evidence? Scottish Geographical Journal, Vol. 131(2), pp. 78-97. https://doi.org/10.1080/14702541.2014.988288

20. Statistics Poland. 2021. Available at https://bdl.stat.gov.pl (accessed on 05/09/2021).

21. Stawicki, M., Vaznoniene, G. 2019. Assessment of Rural Social Infrastructure Services in Lithuania and Poland in the context of Green Economy. Proceedings of the 9th International Scientific Conference Rural Development 2019, pp. 478-485. https://doi.org/10.15544/RD.2019.072

22. Straka, J., Tuzova, M. 2016. Factors Affecting Development of Rural Areas in the Czech Republic. Acta Universitatis Agriculturae et Silviculturae Mendelianae Brunensis, Vol. 64(6), pp. 2141-2150. https://doi.org/10.11118/actaun201664062141

23. Swanson, L. 1992. Rural Social Infrastructure, in: J.N. Reid (ed.), Foundations of Rural Development Policy, Westview Press, Boulder, pp. 62-67.

24. Walaszek, M. 2018. Dostępność Przestrzenna Szkół w Badaniach Usług Edukacyjnych - Przykład Aglomeracji Poznańskiej (Spatial Accessibility of Schools in Educational Services Research - An Example of the Poznan Agglomeration). Rozwój Regionalny i Polityka Regionalna, Vol. 43, pp. 109-122. 
25. Wojewódzka-Wiewiórska, A., Atkociuniene, V. 2019. New View to the Living Conditions in Rural Areas. Proceedings of the 9th International Scientific Conference Rural Development 2019, pp. 515-520. https://doi.org/10.15544/RD.2019.079

26. Wojewódzka-Wiewiórska, A., Stawicki, M. 2020. Uneven Demographic Changes as a Challenge to Provide Access to Education in the Rural Areas in Poland. European Journal of Sustainable Development, Vol. 9(1), pp. 253-262. https://doi.org/10.14207/ejsd.2020.v9n1p253

27. Wojewódzka-Wiewiórska, A., Stawicki, M. 2021. Reflections on the Closure of Rural Schools in the Local Socio-economic Context - The Example of Poland, Lex Localis. Journal of Local Self-Government, Vol. 19, No. 4, pp. 943-965. https://doi.org/10.4335/19.3.943-965(2021) 